\title{
Effect of ultrasound on herpes simplex virus infection in cell culture
}

\author{
Motoko Shintani, Gen Takahashi, Masakazu Hamada, Shyusuke Okunaga, Soichi Iwai and Yoshiaki Yura*
}

\begin{abstract}
Background: Ultrasound has been shown to increase the efficiency of gene expression from retroviruses, adenoviruses and adeno-associated viruses. The effect of ultrasound to stimulate cell membrane permeabilization on infection with an oncolytic herpes simplex virus type 1 (HSV-1) was examined.

Results: Vero monkey kidney cells were infected with HSV-1 and exposed to $1 \mathrm{MHz}$ ultrasound after an adsorption period. The number of plaques was significantly greater than that of the untreated control. A combination of ultrasound and microbubbles further increased the plaque number. Similar results were obtained using a different type of HSV-1 and oral squamous cell carcinoma (SCC) cells. The appropriate intensity, duty cycle and time of ultrasound to increase the plaque number were $0.5 \mathrm{~W} / \mathrm{cm}^{2}, 20 \%$ duty cycle and $10 \mathrm{sec}$, respectively. Ultrasound with microbubbles at an intensity of $2.0 \mathrm{~W} / \mathrm{cm}^{2}$, at $50 \%$ duty cycle, or for $40 \mathrm{sec}$ reduced cell viability.
\end{abstract}

Conclusion: These results indicate that ultrasound promotes the entry of oncolytic HSV-1 into cells. It may be useful to enhance the efficiency of HSV-1 infection in oncolytic virotherapy.

\section{Background}

Oncolytic virotherapy is a novel way to destroy tumor cells using the cytopathic effect of non-virulent viruses [1-4]. Herpes simplex virus type 1 (HSV-1) vectors that lack the neurotoxic gene $\gamma_{1} 34.5$ have been developed and several vectors are under clinical trials [5-7]. A draw back of oncolytic virotherapy for solid tumors is the efficiency of infection. Many factors affect an infection. One important characteristic of the tumor microenvironment is the combination of a leaky vasculature and a lack of functional lymphatics, which can create increased interstitial fluid pressures $[8,9]$. Additional factors in the extracellular matrix of tumors can limit interstitial transport and as a result, further prevent the sufficient and uniform distribution of anti-cancer agents, especially large agents such as virus vectors $[10,11]$. The most reliable way to deliver oncolytic HSV-1 to solid tumors is direct inoculation, through a more efficient method of delivering HSV-1 to each tumor cell is required [7].

Ultrasound has been used diagnostically and therapeutically for decades, and its safety is well established $[12,13]$. Moreover, ultrasound as a means of stimulating

\footnotetext{
*Correspondence: yura@dent.osaka-u.ac.jp

Department of Oral and Maxillofacial Surgery, Osaka University Graduate School of Dentistry, 1-8 Yamadaoka, Suita, Osaka 565-0871, Japan
}

cell membrane permeabilization, sonoporation, offers advantages over other technologies, primarily as a result of its relatively non-invasive nature $[14,15]$. It enhances the antitumor effect of chemotherapeutic agents and the delivery of plasmid DNA in vitro and in vivo $[16,17]$. The transiently increased permeability of the cell membrane is one of the mechanisms of ultrasound-enhanced chemotherapy. Usually, microbulles increased the efficiency of ultrasound exposure. Furthermore, ultrasound has been shown to increase the efficiency of gene expression from retroviruses, adenoviruses and adeno-associated viruses (AVVs) [18-21]. However, this method has not been applied to relatively large enveloped DNA viruses such as HSV-1. In the present study, we examined whether the infection of oncolytic HSV-1 is affected by ultrasound in the presence or absence of microbubbles.

\section{Materials and methods \\ Cell culture and virus}

The human oral squamous cell carcinoma (SCC) cell line SAS was obtained from the Japanese Collection of Research Bioresources (Tokyo, Japan). SAS cells were cultured in Dulbecco's modified Eagle's medium (DMEM) supplemented with 10\% fetal bovine serum, $2 \mathrm{mM} \mathrm{L}$-glutamine, $100 \mathrm{U} / \mathrm{ml}$ penicillin, and $100 \mu \mathrm{g} / \mathrm{ml}$ 
streptomycin and grown in an incubator at $37^{\circ} \mathrm{C}$ in a humidified atmosphere with $5 \% \mathrm{CO}_{2}$. For Vero monkey kidney cells, Eagle's minimal essential medium containing $5 \%$ calf serum and $2 \mathrm{mM}$ L-glutamine was used. The HSV-1 mutant R849 [22] and HF [23,24] were grown in semi-confluent Vero cell monolayers. Infected cells were subjected to three cycles of freezing and thawing and then centrifuged at $3,000 \times \mathrm{g}$ for $15 \mathrm{~min}$ at $4^{\circ} \mathrm{C}$. The supernatant was kept at $-80^{\circ} \mathrm{C}$ prior to use.

\section{Plaque assay}

Cell monolayers were infected with virus serially diluted 10 -fold. After an adsorption period of $60 \mathrm{~min}$, unadsorbed viruses were removed by washing cell monolayers with phosphate-buffered saline (PBS) and then covered with medium containing $0.3 \%$ methylcellulose. They were incubated at $37^{\circ} \mathrm{C}$ in a humidified atmosphere with $5 \% \mathrm{CO}_{2}$ for approximately $48 \mathrm{~h}$. After the development of cytopathic effect, the cells were fixed in methanol, and stained by $1 \%$ crystal violet. The numbers of plaques was counted and plaque forming units (PFU)/ml were determined [25].

\section{Reagents and plates}

As a microbubble, AS-0100 (Artison, Inola, OK) was used. This lipid-shelled ultrasound contrast agent filled with perfluorocarbon gas is composed of $9.8 \times 10^{8}$ microbubbles/ml, having an average diameter of $2.4 \mu \mathrm{m}$. A 24-well plate with a lumox TM fluorocarbon film base was purchased from Greiner bio-one (Gottingen, Germany). The thickness of the gas-permeable film was $50 \mu \mathrm{m}$.

\section{Ultrasound}

An ultrasound machine, Sonitron 2000 V (NEPAGENE Japan, Chiba, Japan), was used. The cells were grown onto alternate 24-well polystylene plates (Corning, NY) to prevent the exposure of neighboring cells [26]. Confluent cell monolayers were infected with 50 or 100 PFU of HSV-1. For sonoporation in the presence of microbubbles, virus in $90 \mu \mathrm{l}$ of DMEM was mixed with microbubbles $\left(9.8 \times 10^{6}\right.$ / $10 \mu \mathrm{l})$, after which the mixture was added to the cell cultures. The transducer was firmly fixed to a stand to avoid dislocation during exposure to ultrasound and the plates were placed on the head of the transducer with a diameter of $12 \mathrm{~mm}$ and contact was mediated using an ultrasound contact gel. After a period of viral adsorption, cells were exposed to ultrasound in the presence or absence of microbubbles. The ultrasound frequency was $1 \mathrm{MHz}$ throughout the experiments. In an initial experiment, the ultrasound was adjusted to supply an intensity of $1.0 \mathrm{~W} / \mathrm{cm}^{2}$ (spatial average temporal peak) at a duty cycle of $10 \%$ (the pulse repetition rate, $100 \mathrm{~Hz}$ ) for $20 \mathrm{sec}$. To determine optimal conditions, the parameters including intensity, duty cycle and period of exposure were changed.
After the exposure, the mixture was removed and the cells were washed with PBS and subjected to a plaque formation assay. Experiments were divided into groups: virus infection only (Control); infection in the presence of microbubbles (MB); infection with ultrasound (US); infection with ultrasound in the presence of microbubbles (MB + US).

In the experiments to determine cell viability, dissociated cells $\left(1 \times 10^{6} / 900 \mu \mathrm{l}\right)$ were mixed with microbubbles $\left(9.8 \times 10^{7} / 100 \mu \mathrm{l}\right)$ and suspended in 48 -well plates. After ultrasound, $1 \times 10^{4}$ cells were inoculated in 96well plates.

\section{3-(4,5-dimethylthiazol-2-yl)-2,5-diphenyl-tetrazolium bromide (MTT) assay}

Cells inoculated in 96-well plates were incubated for $48 \mathrm{~h}$. Thereafter, $10 \mu \mathrm{l}$ of a $5 \mathrm{mg} / \mathrm{ml}$ MTT (Sigma, St.Louis, MO) solution was added to each well with $100 \mu \mathrm{l}$ of medium and cells were incubated at $37^{\circ} \mathrm{C}$ for $4 \mathrm{~h}$. After the addition of $100 \mu \mathrm{l}$ of $0.04 \mathrm{~N} \mathrm{HCl}$ in isopropanol, the plates were mixed thoroughly to dissolve the dark blue crystal and stood at room temperature overnight. The plates were read on a Benchmark Plus microplate spectrophotometer (Bio-Rad Laboratories, Hercules) with a reference wavelength of $630 \mathrm{~nm}$ and a test wavelength of $570 \mathrm{~nm}$. Background absorbance at $630 \mathrm{~nm}$ was subtracted from the $570 \mathrm{~nm}$ reading. The values were divided by that of the control and the rate was calculated.

\section{Statistical analysis}

All values were expressed as the mean \pm SD. An Anova test was used to determine the significance of differences in multiple comparisons. The Mann-Whitney U-test was used to compare plaque numbers and cell viability between each treatment group and the control, and between the ultrasound group and ultrasound with microbubble group. These statistical analyses were performed using the software Statcel2, version 2 (OMS, Tokyo, Japan). A value of $\mathrm{P}<0.05$ was considered to be statistically significant.

\section{Results}

Effect of microbubbles on the infectivity of HSV-1

Whether microbubbles, AS-0100, could affect the infectivity of HSV-1 R849 was examined. Microbubbles $(9.8 \times$ $\left.10^{7} / 100 \mu \mathrm{l}\right)$ were mixed with viral solution $\left(1 \times 10^{7} \mathrm{PFU} /\right.$ $900 \mu \mathrm{l})$. These mixtures were placed at $4^{\circ} \mathrm{C}$. After an incubation for 10,30 , or $60 \mathrm{~min}$, the mixtures were serially diluted with cold PBS and subjected to plaque assays on Vero cell monolayers. It was found that the plaque numbers in the mixtures incubated at $4^{\circ} \mathrm{C}$ for 60 min were not significantly decreased (Figure 1). When $3 \times 10^{7} \mathrm{PFU}$ of another HSV-1 strain, HF, were mixed with microbubbles, no significant reduction in plaque numbers was observed. 


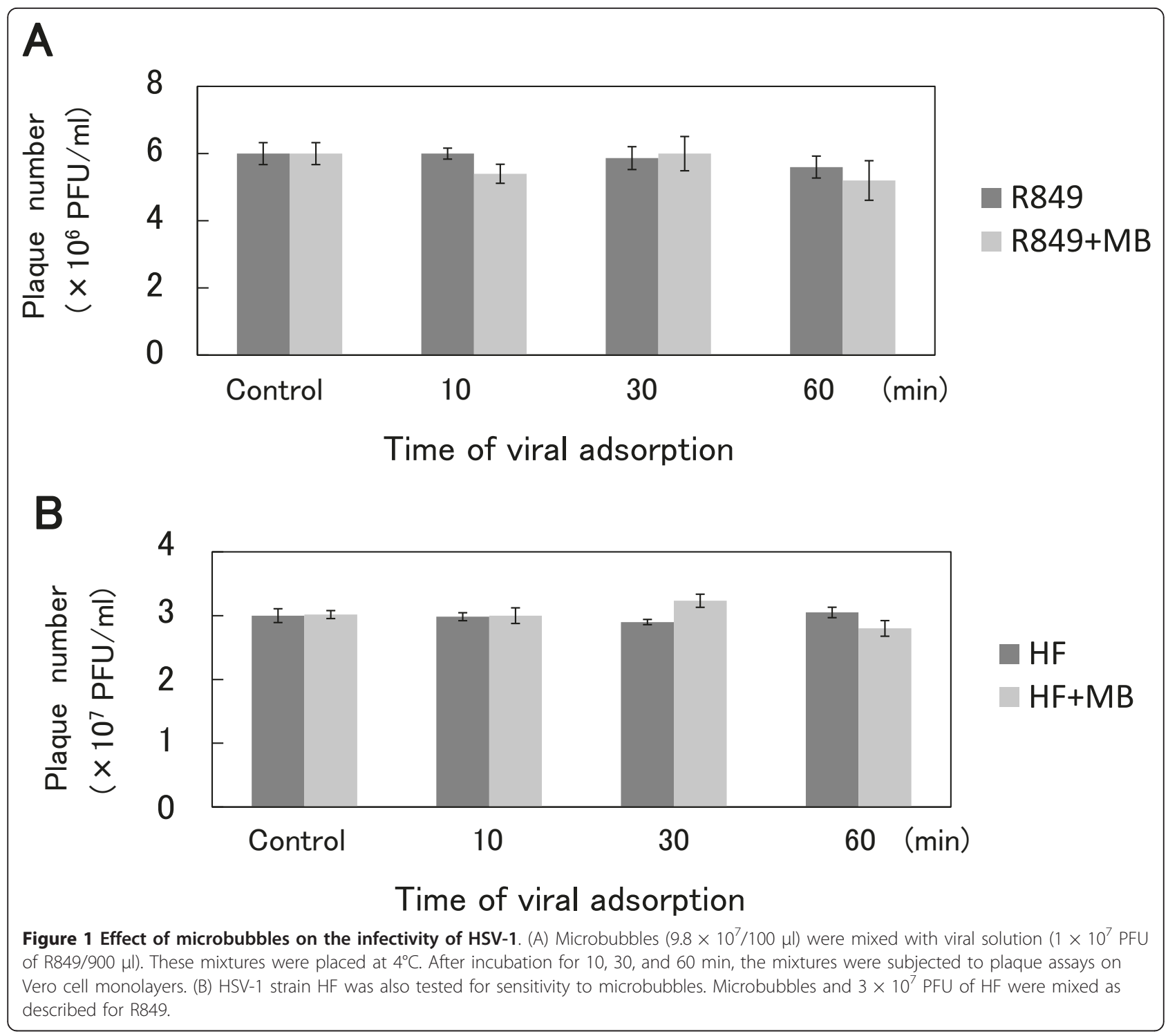

Effect of ultrasound on the plaque formation by $\mathrm{R} 849$ in Vero cell monolayers

Since viruses attach to the cell surface and enter into cells in a time-dependent manner, the number of plaques increases on prolonging the adsorption period. To determine the effect of ultrasound on viral entry, Vero cells were inoculated with 100 PFU of R849 with or without microbubbles. After incubation at $37^{\circ} \mathrm{C}$, infected cells were exposed to ultrasound and then unadsorbed viruses were removed and cells were incubated for plaque formation. The intensity, duty cycle and exposure time were $1.0 \mathrm{~W} / \mathrm{cm}^{2}, 10 \%$ and $20 \mathrm{sec}$, respectively. In the cultures exposed to ultrasound after 10,30 or 60 min of adsorption, mean plaque numbers were increased 1.2-fold, 1.5-fold and 1.3-fold as compared with the control, respectively (Figure 2). In the presence of microbubbles, the increases by ultrasound after 10, 30 or 60 min were 1.9-fold, 1.8-fold and 1.4-fold as compared with the control, respectively. There was a significant difference between the control group and ultrasound group $(\mathrm{P}<$ $0.05)$ or ultrasound with microbubbule group $(\mathrm{P}<0.01)$. A significant difference $(\mathrm{P}<0.05)$ was also observed between the ultrasound group and ultrasound with microbubble group. There was no increase in the experiment with microbubbles only.

\section{Effect of ultrasound on the plaque formation by HF in} Vero cells and by R849 in oral SCC cells

The HSV-1 mutant HF was fusogenic and produced large plaques in Vero cells. The inoculation was reduced to 50 PFU. After $30 \mathrm{~min}$ of adsorption, cells were exposed to ultrasound in the presence or absence of microbubbles. 


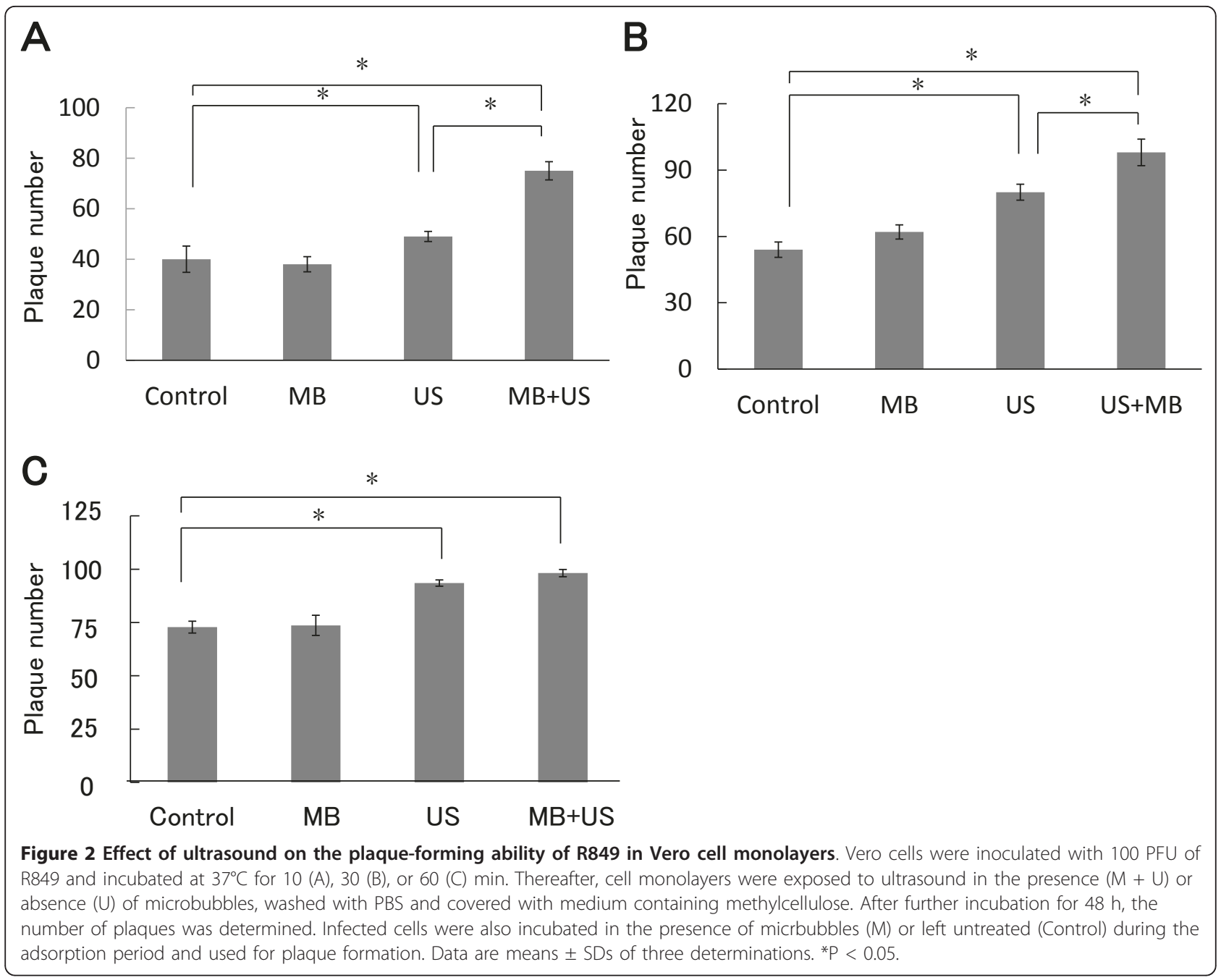

The mean number of plaques was significantly $(\mathrm{P}<0.05)$ greater than that of the control (Figure 3A).

The effect of ultrasound was also examined in human oral SCC SAS cells. Cell monolayers were inoculated with 100 PFU of R849. After 30 min of adsorption, cells were exposed to ultrasound as described for Vero cell monolayers. The increases in plaque numbers caused by ultrasound or ultrasound with microbubbles were 1.5- fold and 1.8-fold as compared with the control (Figure 3B).

The transparent base of the lumox TM multiwall is made of an ultra thin gas-permeable film with low autofluorescence [27]. Vero cells were grown on lumox ${ }^{\mathrm{TM}}$ multiwall plates and infected with 100 PFU of R849. When cells were exposed to ultrasound after $30 \mathrm{~min}$ of adsorption in the absence or presence of microbubbles, the mean numbers of plaque were increased 1.5-fold and 1.7-fold as compared with the control (Figure 3C). The difference between the control group and ultrasound or ultrasound with microbubble group was significant $(P<0.05)$. In the presence of microbubbles, the number of plaques was further increased.

\section{Effect of ultrasound intensity, duty cycle, and exposure time on the formation of plaques by HSV- 1}

In the above experiments, cells were exposed to ultrasound under conditions used for chemotherapeutic drugs and plasmid DNA $[28,29]$. To determine the optimal conditions for HSV-1 infection, experiments were undertaken at 30 min after infection, using Vero cells and R849. First, the duty cycle and exposure time were fixed to $10 \%$ and $20 \mathrm{sec}$, and the ultrasound intensity was changed from 0.5 to 2.0 $\mathrm{W} / \mathrm{cm}^{2}$. The mean plaque number reached a maximal level at $0.5 \mathrm{~W} / \mathrm{cm}^{2}$ (Figure $4 \mathrm{~A}$ ). Microbubbles further increased the plaque number and the difference between the ultrasound group and ultrasound with microbubble group was significant $(\mathrm{P}<0.05)$. However, at $2.0 \mathrm{~W} / \mathrm{cm}^{2}$, the plaque number was decreased as compared with the control. Cell shrinkage and enlarged intercellular spaces were observed 


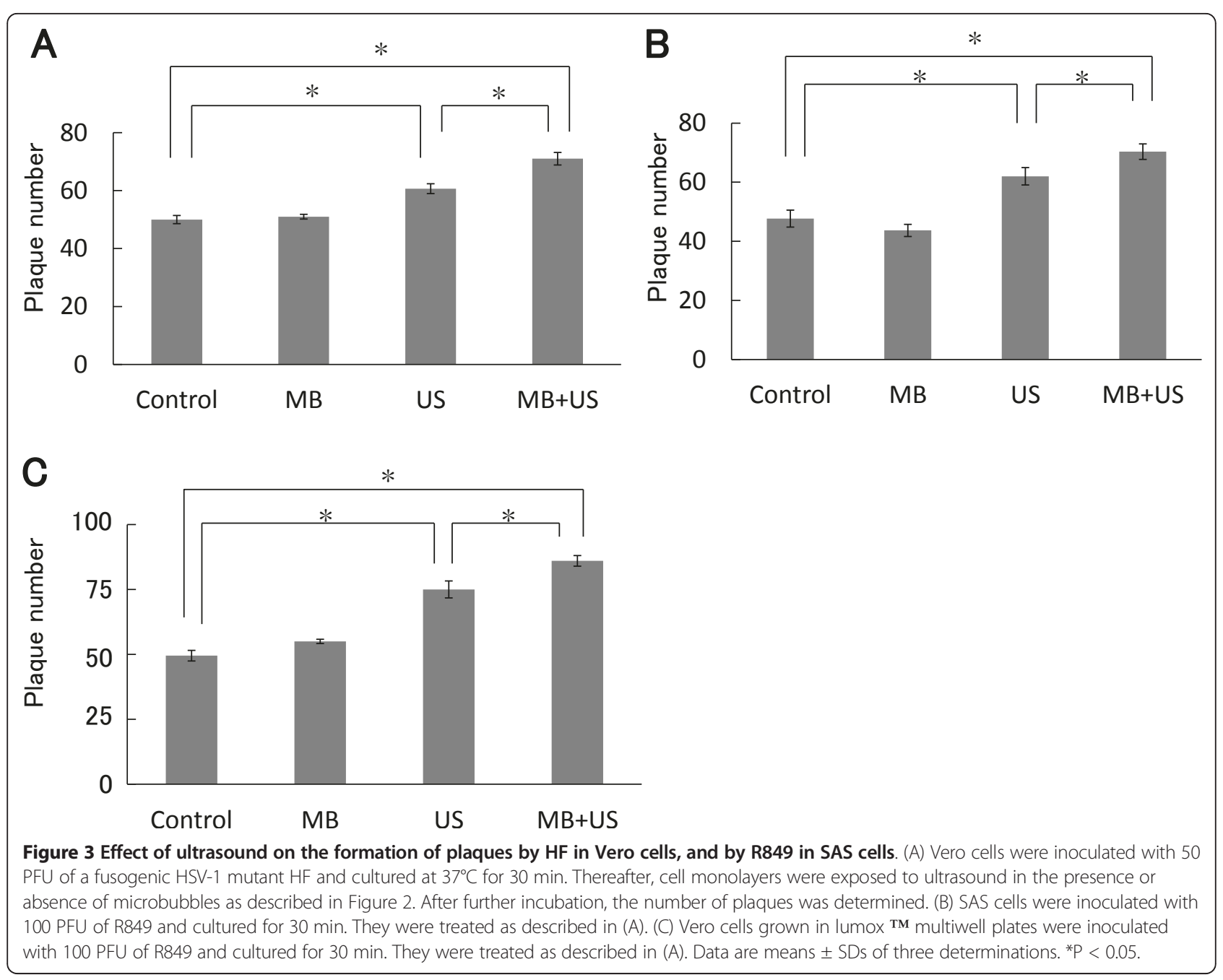

(Figure 4B). On microscopic observation of plaques, control cells remained attached to the plate, whereas most cells exposed to ultrasound were lost. Second, the output intensity and exposure time were fixed to $0.5 \mathrm{~W} / \mathrm{cm}^{2}$ and $20 \mathrm{sec}$, and the duty cycle was changed. A duty cycle ranging from $5 \%$ to $20 \%$ increased the plaque number, with the maximum effect achieved at 20\% (Figure 4C). Microbubbles further increased plaque numbers. At a duty cycle of $50 \%$, however, the plaque number decreased in the presence of microbubbles. Third, the output intensity and duty cycle were fixed at $0.5 \mathrm{~W} / \mathrm{cm}^{2}$ and $20 \%$ and the exposure time was changed from 5 to $40 \mathrm{sec}$. The plaque numbers reached a maximal level at $10 \mathrm{sec}$ (Figure 4D). There was a significant $(\mathrm{P}<0.05)$ difference between the ultrasound group and ultrasound with microbubble group.

\section{Effect of ultrasound and microbubbles on the infectivity of HSV-1}

To determine whether ultrasound and microbubbles could affect the infectivity of HSV-1 R849, viral solution $\left(8 \times 10^{4}\right.$
PFU/180 $\mu \mathrm{l})$ was mixed with microbubbles $\left(1.9 \times 10^{6} /\right.$ $20 \mu \mathrm{l})$ in a 24 -well plate and then exposed to ultrasound irradiation. The intensity, duty cycle and exposure time were $0.5 \mathrm{~W} / \mathrm{cm}^{2}, 20 \%$ and $10 \mathrm{sec}$, respectively. In unirradiated control, PBS was added instead of microbubbles. When the mixtures were subjected to plaque assay, the mean titers in unirradiated control, ultrasound only, and ultrasound with microbubbles were $3.5 \times 10^{5} \mathrm{PFU} / \mathrm{ml}$, $3.2 \times 10^{5} \mathrm{PFU} / \mathrm{ml}$, and $3.4 \times 10^{5} \mathrm{PFU} / \mathrm{ml}$, respectively. There was no reduction of the infectivity of R 849 by ultrasound in the presence or absence of microbubbles.

\section{Effect of ultrasound on cell viability}

To determine the effect of ultrasound on cell viability, uninfected SAS cells were exposed to ultrasound in cell suspensions and cell viability was measured by MTT assay. First, the duty cycle and exposure time were fixed to $10 \%$ and $20 \mathrm{sec}$, and output intensity was changed from 0.5 to $2.0 \mathrm{~W} / \mathrm{cm}^{2}$. From 0.5 to $1.5 \mathrm{~W} / \mathrm{cm}^{2}$, cell viability was slightly increased, but it was decreased to $89 \%$ 


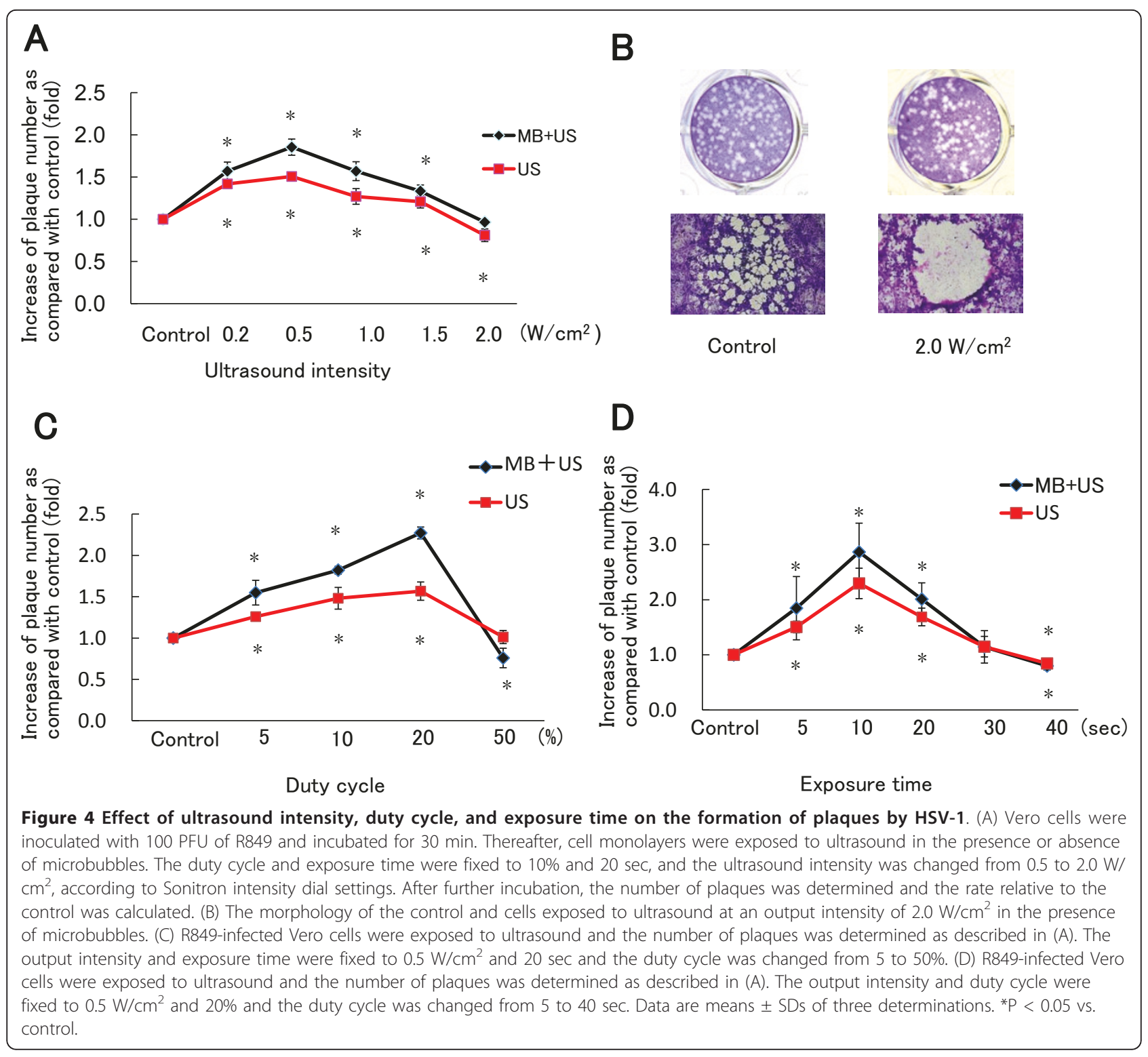

of the control at an intensity of $2.0 \mathrm{~W} / \mathrm{cm}^{2}$ in the presence of microbubbles (Figure 5A). Second, when the duty cycle of ultrasound was changed, cell viability decreased to $92 \%$ of the control at a duty cycle of $50 \%$ in the presence of microbubbles (Figure 5B). Third, when exposure time for ultrasound was changed, cell viability decreased to $81 \%$ of the control after exposure for $40 \mathrm{sec}$ in the presence of microbubbles (Figure $5 \mathrm{C}$ ). There were significant differences $(\mathrm{P}<0.05)$ between the control group and ultrasound with microbubble group.

\section{Discussion}

Ultrasound has been studied extensively as a delivery method for chemotherapeutic agents and plasmid DNA because of its low invasiveness, but studies using infectious viruses are limited. For transduction of the green fluorescence protein (GFP) gene, Li et al. [30] tested three ultrasound contrast agents, Albunex (an albumin-shelled contrast agent composed of air-filled microbubbles), Optison (a perfluorocarbon-filled contrast agent) and Levovist (a galactose-based and air-filled contrast agent). They indicated that the mean number of GFP-transfected cells was approximately 8-fold greater in the presence of Optison than Albunex or Levovit. In the present study, we used AS-0100 composed of a lipid shell containing perfluorocarbon gas. First, we tested the sensitivity of HSV-1 to the microbubbles but found no apparent reduction in plaqueforming ability after incubation for $60 \mathrm{~min}$. Therefore, the microbubbles did not affect the infectivity of HSV-1. 


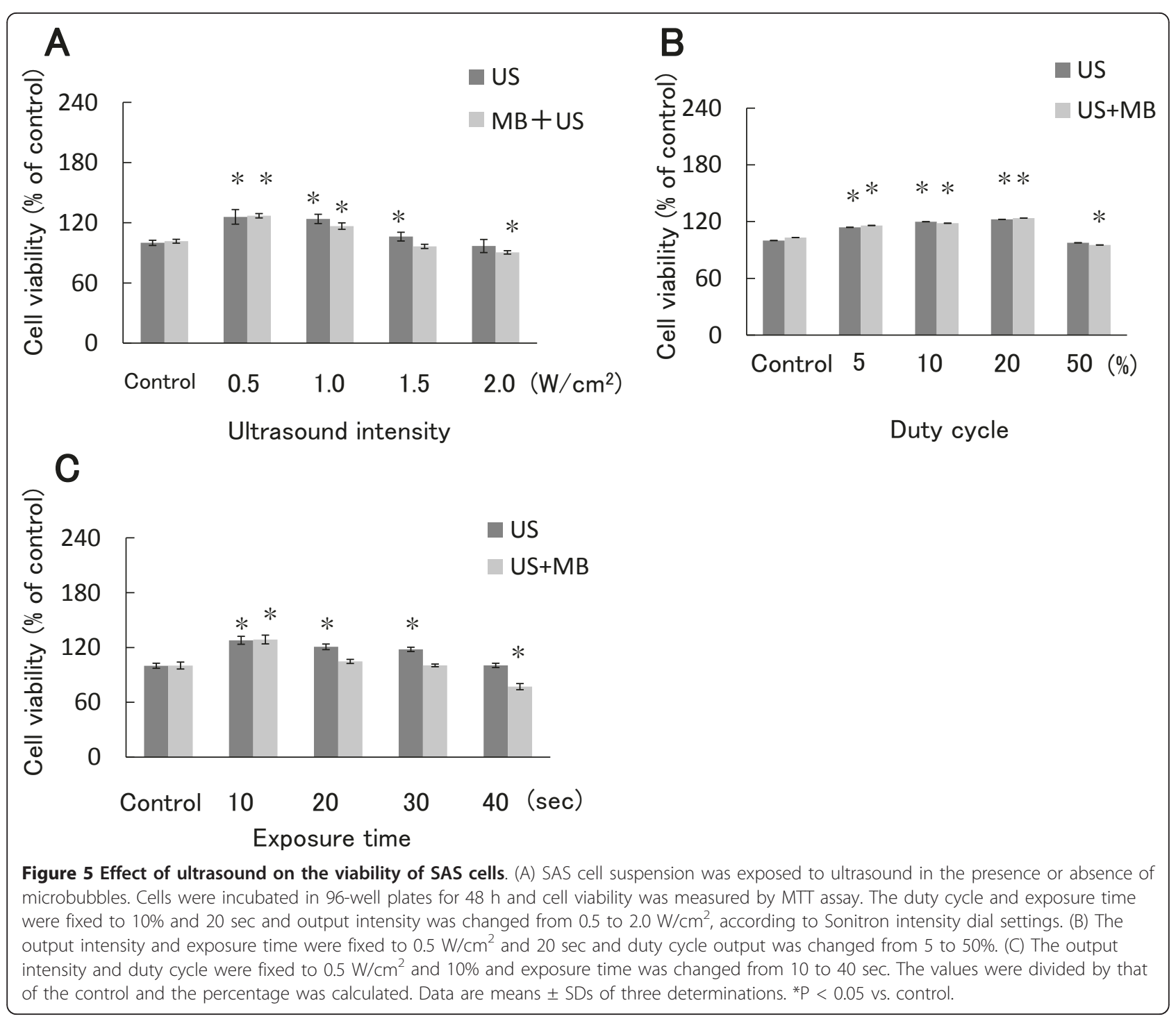

Howard et al. [19] reported that an adenovirus carrying the GFP marker gene could be transduced efficiently into human prostate, lung and melanoma cells via ultrasound exposure in the presence of microbubbles, but not with ultrasound only. Ultrasound with microbubbles also enhanced the expression of GFP encoded in AAV [21]. Although these studies demonstrated the efficiency of gene expression by ultrasound, the effect on the entry of the virus was not studied. In the present study, cells were inoculated with 100 PFU of HSV-1 and exposed to ultrasound after different time intervals. Indeed, when cells were exposed to ultrasound after a period of viral adsorption, the plaque number significantly increased. The effect of ultrasound was not confined to a specific strain of virus or cell line. Furthermore, the infectivity of R849 was not affected by ultrasound irradiation in the presence of absence of microbubbles. Thus, we concluded that ultrasound could accelerate the entry of oncolytic HSV-1 into oral SCC cells. Even in experiments using a lumox TM multiwell plate with a thin fluorocarbon film, a similar enhancement of plaque-forming activity was observed. The findings obtained with polystylene plates may be equivalent to those for the lumox ${ }^{\mathrm{TM}}$ plate.

Li et al. [21] infected to human retinal pigmented epithelial cells with AAV under ultrasound conditions, namely, $1.0 \mathrm{~W} / \mathrm{cm}^{2}$, a duty cycle of $20 \%$ and an exposure period of $20 \mathrm{sec}$ and found an increase in the GFP-positive rate from 17 to $32 \%$. We performed experiments in a variety of conditions and found that an intensity of $0.5 \mathrm{~W} / \mathrm{cm}^{2}$, duty cycle of $20 \%$ and exposure time of $10 \mathrm{sec}$ were the optimal parameters to attain a maximal number of plaques. It is essential to optimize parameters for the efficient transduction of HSV-1. Recently, Kopechek et al. [31] calculated the acoustic output in a cell-well plate, 
using Sonitron 1000 and 2000 and 3 types of transducer. Although the experimental conditions were not identical to ours, their results must be useful to estimate the peakto-peak acoustic pressure at Sonitron intensity settings. Li et al. [21] also examined the effect of the ratios of microbubbles to cells and found that the percentage of transfection efficiency in 50:1 group was increased as compared with 20:1 group. In the present study, we used microbubbles following the recommendation by the manufacturer, so that the ratio of microbubbles to cells was approximately 20:1 for HSV-1 infection. Although the optimal ratio remained to be clarified, it can be stated that the amounts of microbubbles used were sufficient to promote the entry of HSV-1 into epithelial cells.

In cancer therapy, the cytotoxicity of ultrasound would concomitantly have cell-killing effects [32,33]. However, if cell viability was impaired by sonoporation, the replication and antitumor ability of virus would be blunted. We found that ultrasound exposure at $2 \mathrm{~W} / \mathrm{cm}^{2}$ induced changes in cell morphology and decreased cell viability. Duty cycle and exposure time also affected the cell viability. Less invasive conditions are required for efficient HSV-1 infection. In the study of plaque assay, confluent monolayers are required during virus adsorption. When confluent monolayers were exposed to ultrasound, further growth of cells is not expected and only severe cell damage can be detectable by MTT assay. Thus, we decided to use cell suspension and plated the cells after ultrasound for MTT assay. The re-plated cells proliferated at a similar rate as unirradiated cells, if the intensity, duty cycle and time were within a range. This is consistent with the result of plaque assay in which monolayers were used and no cytotoxic alteration of cell morphology occurred except for the condition at high ultrasound intensity (Figure 4B). Although the difference in exposure conditions including cell adhesion and well size may yield distinctly different results, it is unlikely that ultrasound induces lytic changes of the cell membrane to facilitate the virus entry. If this is the case, the number and size of plaques formed in Vero and SAS cell monolayers would be reduced, because plaque formation is dependent on the viability of cells.

In HSV-1 infection, as an initial step, glycoproteins gB and $\mathrm{gC}$ bind to heparin sulfate proteoglycans on the cell surface, attaching the virus to the host cell. Once the viral and host cell membranes are brought close to each other, glycoprotein $\mathrm{gD}$ can associate with any of a number of cell receptors including herpesvirus entry mediator (HVEM), nectin-1 and 3-O-sulfated heparin sulfate to trigger fusion. However, at least three pathways are implicated in HSV-1's entry into different types of susceptible cells: direct fusion with the host cell membrane, endocytosis followed by fusion with an acidic endosome, and endocytosis followed by fusion with a neutral endosome [34-36]. Taylor et al. [20] introduced envelope-deficient retroviral vectors into human rhabdomyosarcoma cells, suggesting that an unenveloped-retrovirus could enter the cells through ultrasound-generated pores of the plasma membrane. We found efficient entry by ultrasound, and a further increase with microbubbles. It is possible that the ultrasound-induced formation of pores contributes to the entry of HSV-1. If so, a similar increase in plaque number should be observed, irrespective of the adsorption period. However, ultrasound produced more plaques after $30 \mathrm{~min}$ of adsorption than 10 min of adsorption. For example, the increases in cultures treated after 10 or $30 \mathrm{~min}$ of adsorption were 10 and 27 PFU, respectively (Figure 2a, b). Thus, another mechanism would be present. In this regard, Hernot and Klibanov [37] proposed the involvement of active transport mechanisms, such as endocytosis and phagocytosis, in the uptake of microbubbles under ultrasound. In the entry of HSV-1 that attaches to the cell surface, endocytosis may be promoted by ultrasound. These in vitro data must be useful to demonstrate the efficacy of sonoporation in introducing R849 and HF into oral SCC xenografts in nude mice.

\section{Conclusion}

The exposure of Vero cells and oral SCC cells to ultrasound can accelerate the process of HSV-1 infection. Microbubbles further enhanced the effect of ultrasound. Ultrasound may be useful to enhance the efficiency of HSV-1 infection in oncolytic virotherapy for oral SCC.

\section{Acknowledgements}

This study was supported in part by a Grant-in-Aid for Scientific Research from the Ministry of Education, Science and Culture of Japan. We thank Dr. Tachibana K. (Fukuoka University) for his helpful advice.

\section{Authors' contributions}

MS performed major part of the experiments, GT contributed to the design and conduction of ultrasound studies, MH performed statistical analysis, SI participated in drafting the manuscript, SO performed experiments for virus stability and YY was responsible for the project and for the preparation of the manuscript.

\section{Competing interests}

The authors declare that they have no competing interests.

Received: 1 April 2011 Accepted: 22 September 2011 Published: 22 September 2011

\section{References}

1. Martuza RL, Malick A, Market JM, Ruffner KL, Coen DM: Experimental therapy of human glioma by means of genetically engineered virus mutant. Science 1991, 252:854-856.

2. Nemunaitis J, Ganly I, Khuri F, Arseneau J, Kuhn J, McCarty T, Landers S, Maples P, Romel L, Randlev B, Reid T, Kaye S, Kirn D: Selective replication and oncolysis in p53 mutant tumors with ONYX-015, an E1B-55kD genedeleted adenovirus, in patients with advanced head and neck cancer: a phase II trial. Cancer Res 2000, 15:6359-6366.

3. Dingli D, Peng KW, Harvey ME, Greipp PR, O'Connor MK, Cattaneo R, Morris JC, Russell SJ: Image-guided radiovirotherapy for multiple 
myeloma using a recombinant measles virus expressing the thyroidal sodium iodide symporter. Blood 2004, 103:1641-1646.

4. Nakamori M, Fu X, Rousseau R, Chen SY, Zhang X: Destruction of nonimmunogenic mammary tumor cells by a fusogenic oncolytic herpes simplex virus induces potent antitumor immunity. Mol Ther 2004, 9:658-665.

5. Mineta T, Rabkin SD, Yazaki T, Hunter WD, Martuza RL: Attenuated multimutated herpes simplex virus-1 for the treatment of malignant gliomas. Nat Med 1995, 1:938-943.

6. Kemeny N, Brown K, Covey A, Kim T, Bhargava A, Brody L, Guilfoyle B, Haag NP, Karrasch M, Glasschroeder B, Knoll A, Getrajdman G, Kowal K, Jarnagin WR, Fong Y: Phase I, open-label, dose-escalating study of a genetically engineered herpes simplex virus, NV1020, in subjects with metastatic colorectal carcinoma to the liver. Hum Gene Ther 2006, 17:1214-1224.

7. Mace AT, Ganly I, Soutar DS, Brown SM: Potential for efficacy of the oncolytic herpes simplex virus 1716 in patients with oral squamous cell carcinoma. Head Neck 2008, 30:1045-1051.

8. Boucher Y, Baxter LT, Jain RK: Interstitial pressure gradients in tissueisolated and subcutaneous tumors: implications for therapy. Cancer Res 1990, 50:4478-4484.

9. Jain RK: Normalization of tumor vasculature: an emerging concept inantiangiogenic therapy. Science 2005, 307:58-62.

10. McKee TD, Grandi P, Mok W, Alexandrakis G, Insin N, Zimmer JP, Bawendi MG, Boucher Y, Breakefield XO, Jain RK: Degradation of fibrillar collagen in a human melanoma xenograft improves the efficacy of an oncolytic herpes simplex virus vector. Cancer Res 2006, 66:2509-2513.

11. Wang Y, Yuan F: Delivery of viral vectors to tumor cells: extracellular transport, systemic distribution, and strategies for improvement. Ann Biomed Eng 2006, 34:114-127.

12. Lindner JR: Molecular imaging with contrast ultrasound and targeted microbubbles. J Nucl Cardiol 2004, 11:215-221.

13. Kaufmann BA, Lindner JR: Molecular imaging with targeted contrast ultrasound. Curr Opin Biotechnol 2007, 18:11-16.

14. Dooley DA, Child SZ, Carstensen EL, Miller MW: The effects of continuous wave and pulsed ultrasound on rat thymocytes in vitro. Ultrasound Med Biol 1983, 9:379-384.

15. Fechheimer M, Boylan JF, Parker S, Sisken JE, Patel GL, Zimmer SG: Transfection of mammalian cells with plasmid DNA by scrape loading and sonication loading. Proc Natl Acad Sci USA 1987, 84:8463-8467.

16. Newman CM, Lawrie A, Brisken AF, Cumberland DC: Ultrasound gene therapy: on the road from concept to reality. Echocardiography 2001, 18:339-347.

17. Frenkel V: Ultrasound mediated delivery of drugs and genes to solid tumors. Adv Drug Deliv Rev 2008, 60:1193-1208.

18. Lee $\mathrm{YH}$, Peng CA: Enhanced retroviral gene delivery in ultrasonic standing wave fields. Gene Ther 2005, 12:625-633.

19. Howard CM, Forsberg F, Minimo C, Liu JB, Merton DA, Claudio PP Ultrasound guided site specific gene delivery system using adenoviral vectors and commercial ultrasound contrast agents. I Cell Physiol 2006, 209:413-421.

20. Taylor SL, Rahim AA, Bush NL, Bamber JC, Porter CD: Targeted retroviral gene delivery using ultrasound. I Gene Med 2007, 9:77-87.

21. Li HL, Zheng XZ, Wang HP, Li F, Wu Y, Du LF: Ultrasound-targeted microbubble destruction enhances AAV-mediated gene transfection in human RPE cells in vitro and rat retina in vivo. Gene Ther 2009, 16:1146-1153.

22. Andreansky S, Soroceanu L, Flotte ER, Chou J, Markert JM, Gillespie GY, Roizman B, Whitley RJ: Evaluation of genetically engineered herpes simplex viruses as oncolytic agents for human malignant brain tumors. Cancer Res 1997, 57:1502-1509.

23. Takakuwa H, Goshima F, Nozawa N, Yoshikawa T, Kimata H, Nakao A, Nawa A, Kurata T, Sata T, Nishiyama Y: Oncolytic viral therapy using a spontaneously generated herpes simplex virus type 1 variant for disseminated peritoneal tumor in immunocompetent mice. Arch Virol 2003, 148:813-825

24. Ogawa F, Takaoka H, Iwai S, Aota K, Yura Y: Combined oncolytic virotherapy with herpes simplex virus for oral squamous cell carcinoma. Anticancer Res 2008, 28:3637-3645.

25. Naito S, Obayashi S, Sumi T, Iwai S, Nakazawa M, Ikuta K, Yura Y: Enhancement of antitumor activity of herpes simplex virus gamma(1) 34.5-deficient mutant for oral squamous cell carcinoma cells by hexamethylene bisacetamide. Cancer Gene Ther 2006, 13:780-791.

26. Kodama T, Tomita Y, Koshiyama K, Blomley MJ: Transfection effect of microbubbles on cells in superposed ultrasound waves and behavior of cavitation bubble. Ultrasound Med Biol 2006, 32:905-914.

27. Tachibana K, Feril LB Jr, Ikeda-Dantsuji Y: Sonodynamic therapy. Ultrasonics 2008, 48:253-259.

28. Imanaga K, Tominaga K, Yamamoto K, Habu M, Maeda H, Akifusa S, Tsujisawa T, Okinaga T, Fukuda J, Nishihara T: Local delivery system of cytotoxic agents to tumors by focused sonoporation. Cancer Gene Ther 2007, 14:354-363.

29. Watanabe $Y$, Aoi A, Horie S, Tomita N, Mori S, Morikawa H, Matsumura Y, Vassaux G, Kodama T: Low-intensity ultrasound and microbubbles enhance the antitumor effect of cisplatin. Cancer Sci 2008, 99:2525-2531.

30. Li T, Tachibana K, Kuroki M, Kuroki M: Gene transfer with echo-enhanced contrast agents: comparison between Albunex, Optison, and Levovist in mice-initial results. Radiology 2003, 229:423-428.

31. Kopechek JA, Kim H, McPherson DD, Holland CK: Calibration of the 1-MHz Sonitron ultrasound system. Ultrasound Med Biol 2010, 36:1762-1766.

32. Ando H, Feril LB Jr, Kondo T, Tabuchi Y, Ogawa R, Zhao QL, Cui ZG, Umemura S, Yoshikawa H, Misaki T: An echo-contrast agent, Levovist, lowers the ultrasound intensity required to induce apoptosis of human leukemia cells. Cancer Lett 2006, 242:37-45.

33. Li YS, Reid CN, McHale AP: Enhancing ultrasound-mediated cell membrane permeabilisation (sonoporation) using a high frequency pulse regime and implications for ultrasound-aided cancer chemotherapy. Cancer Lett 2008, 266:156-162.

34. Spear PG, Manoj S, Yoon M, Jogger CR, Zago A, Myscofski D: Different receptors binding to distinct interfaces on herpes simplex virus $\mathrm{gD}$ can trigger events leading to cell fusion and viral entry. Virology 2006, 344:17-24.

35. Campadelli-Fiume G, Amasio M, Avitabile E, Cerretani A, Forghieri C, Gianni T, Menotti L: The multipartite system that mediates entry of herpes simplex virus into the cell. Rev Med Virol 2007, 17:313-326.

36. Reske A, Pollara G, Krummenacher C, Chain BM, Katz DR: Understanding HSV-1 entry glycoproteins. Rev Med Virol 2007, 17:205-215.

37. Hernot $\mathrm{S}$, Klibanov AL: Microbubbles in ultrasound-triggered drug and gene delivery. Adv Drug Deliv Rev 2008, 60:1153-1166.

doi:10.1186/1743-422X-8-446

Cite this article as: Shintani et al: Effect of ultrasound on herpes simplex virus infection in cell culture. Virology Journal 2011 8:446.

\section{Submit your next manuscript to BioMed Central and take full advantage of:}

- Convenient online submission

- Thorough peer review

- No space constraints or color figure charges

- Immediate publication on acceptance

- Inclusion in PubMed, CAS, Scopus and Google Scholar

- Research which is freely available for redistribution

Submit your manuscript at www.biomedcentral.com/submit
() Biomed Central 